\title{
The complete mitochondrial genome of the pirarucu (Arapaima gigas, Arapaimidae, Osteoglossiformes)
}

\author{
Tomas Hrbek ${ }^{1,2}$ and Izeni Pires Farias ${ }^{1}$ \\ ${ }^{1}$ Laboratório de Evolução e Genética Animal, Instituto de Ciências Biológicas, Manaus, \\ Universidade Federal do Amazonas, AM, Brazil. \\ ${ }^{2}$ Biology Department, University of Puerto Rico, Rio Piedras, San Juan, Puerto Rico.
}

\begin{abstract}
We sequenced the complete mitochondrial genome of the pirarucu, Arapaima gigas, the largest fish of the Amazon basin, and economically one of the most important species of the region. The total length of the Arapaima gigas mitochondrial genome is $16,433 \mathrm{bp}$. The mitochondrial genome contains 13 protein-coding genes, two rRNA genes and 22 tRNA genes. Twelve of the thirteen protein-coding genes are coded on the heavy strand, while nad 6 is coded on the light strand. The Arapaima gene order and content is identical to the common vertebrate form, as is codon usage and base composition. Its control region is atypical in being short at $767 \mathrm{bp}$. The control region also contains a conserved ATGTA motif recently identified in the Asian arowana, three conserved sequence blocks (CSB-1, CBS-2 and CBS-3) and its 3' end contains long series of di- and mono-nucleotide microsatellite repeats. Other osteoglossiform species for which control region sequences have been published show similar control region characteristics.
\end{abstract}

Key words: pirarucu, mitogenomics, Amazon basin.

Received: August 22, 2006; Accepted: July 10, 2007.

\section{Introduction}

Comparing complete animal mitochondrial genome sequences is becoming an increasingly common method of phylogenetic reconstruction and of modeling genome evolution. Mitochondrial genomes from over 300 vertebrate species, with a large concentration on teleost fishes, have now been sequenced (Boore, 1999; Curole and Kocher, 1999; Inoue et al., 2001; Miya et al., 2001; Miya et al., 2003). Mitochondrial sequences have proven to be of great utility in molecular phylogenetic studies, providing large number of phylogenetically informative characters, and complete genome sequences have provided valuable insights into a number of deep-level phylogenetic questions (e.g., Boore and Brown, 1998; Mindell et al., 1998; Naylor and Brown, 1998; Miya et al., 2001; Inoue et al., 2003a; Miya et al., 2003; Brinkmann et al., 2004).

Further information comes from the gene order of mitochondrial genomes. While the gene order among vertebrates is highly conserved (e.g., Inoue et al., 2001, 2003a; Miya et al., 2003), and most animal mitochondrial genomes contain the same 37 intron-less genes (Brown, 1985; Boore, 1999), there are some well documented exceptions

Send correspondence to Tomas Hrbek. Biology Department, University of Puerto Rico, Rio Piedras, San Juan, Puerto Rico. E-mail: hrbek@uprrp.edu. such as the gene order of birds (Mindell et al., 1998; Haring et al., 2001), squamate reptiles (Macey et al., 1997a; Macey et al., 1997b), teleost fishes (Miya and Nishida, 1999; Inoue et al., 2003b), and mammals (Pääbo et al., 1991). These rearrangement to date have not been shown to be homoplaseous, and thus provide high quality phylogenetic information (Boore et al., 1997; Pereira, 2000; Morrison et al., 2002) similar to SINE and LINE data.

The mitochondrial genome is typically compact at $\sim 16 \mathrm{~kb}$ with few, if any, intergenic spacers. The two noncoding regions which usually represent less than $5 \%$ of the total genome size are the control region which contains the heavy-strand replication origin and is involved in regulating of transcription and replication (Clayton, 1982; Shadel and Clayton, 1997), and the light-strand replication origin (Wong and Clayton, 1985). While the structural properties of the control region are important in transcription and replication, actual sequence of nucleotides is relatively free to vary (Shadel and Clayton, 1997) making the control region a popular candidate for population-level and phylogeographic studies (Avise, 2004).

Complete mitochondrial genomes are available for a number of the species of the order Osteoglossiformes, but not for Arapaima gigas. A peculiarity of all of the osteoglossiform genomes deposited in GenBank (AB043025 and AB043068, Inoue et al., 2001), with the exception of 
Scleropages formosus, is that they are all missing the control region. In their conservation genetic study, Hrbek et al. (2005) were also unable to amplify the control region of majority of the individuals used in the study in spite of designing specific, highly stringent primers. Those individuals that amplified often produced only a weak product; amplification of different individuals resulted in different sized products, and some individuals also showed multiple bands. These results pointed to the possible presence of repeats and secondary structures that would prevent efficient amplification and sequencing of this region. Multiple PCR bands suggested possible mtDNA heteroplasmy. Consultation with the authors of the Osteoglossum and Pantodon mitochondrial genomes revealed that they also were unable to efficiently amplify and sequence the control region; only the 5' portion of the control regions are deposited, and are characterized by a large series of tandem repeats. In a recent publication characterizing the complete mitochondrial genome of the Asian arowana Scleropages formosus, Yue et al. (2006) observed tandem repeats in the control region, and also mitochondrial heteroplasmy. Therefore, we sequenced the complete mitochondrial genome of Arapaima gigas, including the control region, in order to characterize the genome and assess its potential phylogenetic utility, and that of its genes and gene regions.

\section{Material and Methods}

\section{Laboratory protocols}

The tissue sample used in this analysis was obtained from a specimen captured in a participatively managed fishery area north of the city of Santarém. A white muscle tissue sample was collected and preserved in 95\% ethanol and transported to laboratory. Total genomic DNA was extracted using Qiagen spin-column according to the manufacturer's protocol.

Polymerase Chain Reaction (PCR) amplification was performed on total genomic DNA. Negative controls were performed for all reactions. PCR was performed in $50 \mu \mathrm{L}$ reaction volumes containing $23.6 \mu \mathrm{L}$ of $\mathrm{ddH}_{2} \mathrm{O}, 3.4 \mu \mathrm{L}$ of $10 \mathrm{mM} \mathrm{MgCl}_{2}, 5.0 \mu \mathrm{L}$ of $10 \mathrm{x}$ buffer $(200 \mathrm{mM}$ Tris- $\mathrm{HCl}[\mathrm{pH}$ 8.8], $20 \mathrm{mM} \mathrm{MgSO} 4,100 \mathrm{mM} \mathrm{KCl}, 100 \mathrm{mM}\left(\mathrm{NH}_{4}\right)_{2} \mathrm{SO}_{4}$, $1 \%$ Triton ${ }^{\circledR} \mathrm{X}-100,1 \mathrm{mg} / \mathrm{mL}$ nuclease-free BSA), $5.0 \mu \mathrm{L}$ of each primer $(2 \mu \mathrm{M}), 4.0 \mu \mathrm{L}$ dNTP mix $(10 \mathrm{mM}), 8$ units of KlenTaqLA DNA Polymerase, and $2 \mu \mathrm{L}$ of DNA template (approximately $50 \mathrm{ng} / \mu \mathrm{L}$ ).

To assure fidelity of priming, we used a touch-down PCR method. The temperature profile consisted of 1) preheating at $68{ }^{\circ} \mathrm{C}$ for $60 \mathrm{~s}, 2$ ) denaturation at $93{ }^{\circ} \mathrm{C}$ for $10 \mathrm{~s}$, 3) annealing at $55-50{ }^{\circ} \mathrm{C}$ for $35 \mathrm{~s}, 4$ ) extension at $68^{\circ} \mathrm{C}$ for $7 \mathrm{~min}$, and 5) a final extension at $68^{\circ} \mathrm{C}$ for $10 \mathrm{~min}$. Steps 2-4 were repeated 25 times; in the first 9 cycles, the annealing temperature was decreased by $0.5{ }^{\circ} \mathrm{C}$ until $50{ }^{\circ} \mathrm{C}$ an- nealing temperature was reached. Using this methodology we amplified three overlapping segments.

PCR products were evaluated on a $1 \%$ agarose gel, and then purified with Qiagen spin-columns. The sequencing strategy employed the 'primer walking' methodology. We sequenced each amplified fragment with the two amplification primers, and upon obtaining the sequence information we performed additional sequencing reactions with internal primers available in the laboratory or specifically designed primers until sequence data were obtained for the complete fragment. Many of the additional primers used in this study were derived from primers published in Miya and Nishida (1999); see Table 1 for primers.

Cycle sequencing PCR followed manufacturer's recommended protocol for DYEnamic ET Dye Terminator mix (GE Healthcare); primer annealing temperature was at $50{ }^{\circ} \mathrm{C}$ and we used $\sim 30 \mathrm{ng}$ of purified PCR product. Cycle sequencing PCR products were precipitated using a mixture of $70 \%$ ethanol and $175 \mathrm{mM}$ ammonium acetate. Precipitated DNA product was resuspended in $\mathrm{Hi}-\mathrm{Di}$ Formamide, and resolved on a MegaBACE 1000 automatic DNA analysis system (GE Healthcare) using the manufacturer's recommended settings.

The complete genome was re-sequenced, providing a $2 \mathrm{x}$ genomic coverage. It was then aligned and annotated against the mitochondrial genome of Osteoglossum bicirrhosum (GenBank\# AB043025).

\section{Data analysis}

Orthologous protein-coding regions were aligned in Clustal W (Thompson et al., 1996), and alignment was confirmed by conceptually translating protein-coding DNA regions into amino-acid sequences in BioEdit (Hall, 1999). Alignments of ribosomal and transfer RNAs were constructed in Clustal W (Thompson et al., 1996) and manually adjusted, if necessary, to conform to secondary structural models (Kumazawa and Nishida, 1993; Ortí et al., 1996; Wang and Lee, 2002; Waters et al., 2002). Codon usage frequencies, and amino acid composition of the genome was inferred in the program MEGA 3.1 (Kumar et al., 2004). Mitochondrial gene regions were tested for an anti$\mathrm{G}$ bias characteristic of the mitochondrial DNA genes, but not of the nuclear genome, to support our conclusion that we have collected genuine mitochondrial DNA data (Zhang and Hewitt, 1996). Hairpins in the control regions were inferred using the software mFold (Zuker, 2003) implemented on the website www.idtdna.com.

\section{Results}

The total length of the Arapaima gigas mitochondrial genome is $16,433 \mathrm{bp}$. The genome sequence is deposited in GenBank under the accession number EF523611. The Arapaima gene order and content (Figure 1 and Table 2) is identical to the ancestral vertebrate state (e.g., Inoue et al., 2001, 2003a; Miya et al., 2003). The genome codes for one 
Table 1 - Primers used in the amplification and sequencing of the complete mitochondrial genome of Arapaima gigas. The primer designations correspond to their 3' position in the human mitochondrial genome (Anderson et al., 1981) by convention. H and L designate the heavy and the light strand, respectively. Many of the primers reported for the first time in this study are used in ongoing studies in our laboratory, or were derived from primers published in Miya and Nishida (1999).

\begin{tabular}{|c|c|c|c|c|}
\hline Location & Primer & Region & Primer sequence & Source \\
\hline & amplification & & & \\
\hline L1090 & $12 \mathrm{Sa}$ & $12 \mathrm{~S}$ & 5'-AAACTGGGATTAGATACCCCACTA-3' & $\begin{array}{c}\text { (Hrbek and } \\
\text { Larson, 1999) }\end{array}$ \\
\hline H8516 & ATPr.1 & ATP8/6 & 5'-CTTAGTGTCATGGTCAGTTTCA-3' & (Hrbek et al., 2005) \\
\hline L8537 & ATPf.1 & ATP8/6 & 5'-TGAAACTGACCATGACACTAAG-3' & (Hrbek et al., 2005) \\
\hline H15149 & $\mathrm{CBr} .4$ & cytb & 5'-CCTCARAAGGATATYTGTCCTCA-3' & This study \\
\hline L15995b & Prof.1 & tRNA $^{\text {Pro }}$ & 5'-CTCYCACCCCTGACTCCCAAAG-3' & This study \\
\hline H693 & $\begin{array}{c}12 \mathrm{Sr} .5 \\
\text { sequencing }\end{array}$ & $12 \mathrm{~S}$ & 5'-GGCGGATACTTGCATGT-3' & This study \\
\hline L185b & Dlf.4 & D-loop & 5'-GGCATTTGGTTCCTATTTCAGG-3' & This study \\
\hline L617 & Phef.1 & $\mathrm{tRNA}^{\mathrm{Phe}}$ & 5'-AAGCATAACATTGAAGATG-3' & This study \\
\hline H693 & $12 \mathrm{Sr} .5$ & $12 \mathrm{~S}$ & 5'-GGCGGATACTTGCATGT-3' & This study \\
\hline L1090 & $12 \mathrm{Sa}$ & $12 \mathrm{~S}$ & 5'-AAACTGGGATTAGATACCCCACTA-3' & $\begin{array}{c}\text { (Hrbek and } \\
\text { Larson, 1999) }\end{array}$ \\
\hline H1067 & 12Sr.4 & $12 \mathrm{~S}$ & 5'-TAGTGGGGTATCTAATCCCAGTTT-3' & This study \\
\hline L1579 & $12 \mathrm{Sf} .2$ & $12 \mathrm{~S}$ & 5'-AAGTCGTAACATGGTAAGTGYAC-3' & This study \\
\hline H1782 & $16 \mathrm{Sr} .3$ & $16 \mathrm{~S}$ & 5’-TTTCATCTTTCCCTTGCGGTAC-3’ & $\begin{array}{c}\text { (Hrbek and } \\
\text { Larson, 1999) }\end{array}$ \\
\hline H2001 & 16Sr.6 & $16 \mathrm{~S}$ & 5'-AACCAGCTATCACCAGGCTCG-3' & This study \\
\hline L2021 & $16 \mathrm{Sf} .3$ & $16 \mathrm{~S}$ & 5'-CGAGCCTGGTGATAGCTGGTT-3' & This study \\
\hline H2493 & 16Sr.5 & $16 \mathrm{~S}$ & 5'-GATGTTTTTGGTAAACAGG-3' & This study \\
\hline L2510 & $16 \mathrm{sf} .5$ & $16 \mathrm{~S}$ & 5'-GCCCTGTTTACCAAAAACAT-3' & This study \\
\hline L3002 & $16 \mathrm{Sf} .2$ & $16 \mathrm{~S}$ & 5'-TACGACCTCGATGTTGGATCAGG-3' & (Hrbek et al., 2005) \\
\hline H3058 & 16Sr.4 & $16 \mathrm{~S}$ & 5'-CCGGTCTGAACTCAGATCACGT-3' & This study \\
\hline L3079 & $16 \mathrm{Sf} .1$ & $16 \mathrm{~S}$ & 5'-ACGTGATCTGAGTTCAGACCG-3' & (Hrbek et al., 2005) \\
\hline L3317 & Leu & tRNA ${ }^{\text {Leu }}$ & 5'-CCGGCCAATGCAAAAGACCTAA-3 & This study \\
\hline L3416 & ND1f.4 & ND1 & 5'-CATACAACTRCGAAAAGGRCC-3' & This study \\
\hline L3899 & ND1f.8 & ND1 & 5'-GAAACAAACCGAGCCCCYTT-3' & This study \\
\hline L4280 & ILEr.4 & tRNA $^{\text {Ile }}$ & 5'-ACTGTATCAAAGTGGYCCTT-3' & (Hrbek et al., 2005) \\
\hline L4299 & ILEf.1 & tRNA $^{\text {Ile }}$ & 5'-AAGGRTTACTTTGATAGAGT-3' & $\begin{array}{c}\text { (Hrbek and } \\
\text { Larson, 1999) }\end{array}$ \\
\hline H4364 & GLNr.2 & $\mathrm{tRNA}^{\mathrm{Gln}}$ & 5'-GGAAGCACTARGAGTTTTGA-3' & This study \\
\hline L4437 & METf.6 & $\mathrm{tRNA}^{\mathrm{Met}}$ & 5’-AAGCTTTYGGGCCCATACC-3' & (Macey et al., 1997a) \\
\hline L4882 & ND2f.14 & ND2 & 5'-TGACAAAARCTAGCCCC-3' & $\begin{array}{c}\text { (Hrbek and } \\
\text { Larson, 1999) }\end{array}$ \\
\hline H4980 & ND2r.6 & $\mathrm{ND} 2$ & 5'-ATTTTTCGTAGTTGGGTTTGRTT-3' & This study \\
\hline $\mathrm{H} 5540$ & TRPr.5 & tRNA $^{\text {Trp }}$ & 5'-TTTAAAGCTTTGAAGGC-3' & $\begin{array}{c}\text { (Hrbek and } \\
\text { Larson, 1999) }\end{array}$ \\
\hline L5550 & TRPf.1 & $\mathrm{tRNA}^{\mathrm{Trp}}$ & 5'-CTAARAGCCTTCAAAGC-3' & This study \\
\hline H5934 & CO1r.1 & $\mathrm{CO} 1$ & 5'-AGRGTGCCAATGTCTTTGTGRTT-3' & (Macey et al., 1997a) \\
\hline L6190 & CO1f.1 & $\mathrm{CO} 1$ & 5'-GCATTTCCGCGAATAAATAA-3' & This study \\
\hline L6717 & CO1f.1 & $\mathrm{CO} 1$ & 5'-TACATRGGAATRGTATGAGC-3' & This study \\
\hline H7414 & CO1r.2 & $\mathrm{CO} 1$ & 5'-GAAAAGCAGGTTCTTCAAATG-3' & This study \\
\hline H7985 & $\mathrm{CO} 2 \mathrm{r} .2$ & $\mathrm{CO} 2$ & 5'-TCGGTGATCTACTTCTAATAGACG-3' & This study \\
\hline L8106 & $\mathrm{CO} 2 \mathrm{f} .1$ & $\mathrm{CO} 2$ & 5'-TGGGTGTTAAAATAGATGC-3' & (Hrbek et al., 2005) \\
\hline H8516 & ATPr.1 & ATP8/6 & 5'-CTTAGTGTCATGGTCAGTTTCA-3' & (Hrbek et al., 2005) \\
\hline
\end{tabular}


Table 1 (cont.)

\begin{tabular}{lccll}
\hline Location & Primer & Region & Primer sequence & Source \\
\hline L8537 & ATPf.1 & ATP8/6 & 5'-TGAAACTGACCATGACACTAAG-3' & (Hrbek et al., 2005) \\
L9158 & ATP6f.1 & ATP6 & 5'-GCMGTAGCTATTATTCAAGC-3' & (Hrbek et al., 2005) \\
H9264 & CO3r.2 & CO3 & 5'-GAGGAGAGCRGCRGATGCCCC-3' & (Hrbek et al., 2005) \\
L9514 & CO3f.1 & CO3 & 5'-TTCTGAGCCTTCTTYCA-3' & This study \\
L10038 & GLYf.1 & tRNA ${ }^{\text {Gly }}$ & 5'-CTTCCAATTATTTAATCTTG-3' & This study \\
L10765 & ND4f.1 & ND4 & 5'-TTAAATCTCTTACAATGCTA-3' & This study \\
L11414 & ND4f.2 & ND4 & 5'-GACTACCAAAAGCCCAYGTAGA-3' & This study \\
H11534 & ND4r.1 & ND4 & 5'-GCTATAACAATAAAGGGGTA-3' & This study \\
L12070 & ND4f.3 & ND4 & 5'-CACATTCACGAGAACACCTTCTCATA-3' & This study \\
L12321 & Leuf.1 & tRNA ${ }^{\text {Leu }}$ & 5'-GGAACCAAAAACTCTTGGTGCAA-3' & This study \\
L12809 & ND5f.6 & ND5 & 5'-ATATCYTTCCTCCTAATTGGTTGATG-3' & This study \\
L13562 & ND5f.3 & ND5 & 5'-TCAYACCTAAAYGCTTCAGCCCT-3' & This study \\
H13600 & ND5r.2 & ND5 & 5'-AAGAAGATTACCCGGAAGCTGTA-3' & This study \\
L13991 & ND5f.7 & ND5 & 5'-GGACAAACCATAGCGTCTCAACT-3' & This study \\
H14080 & ND5r.1 & ND5 & 5'-AGGTAGGTTTTAATTAGACC-3' & This study \\
L14725 & GLUf.3 & tRNA ${ }^{\text {Glu }}$ & 5'-GGCACGAAAAACCGCCGTTG-3' & This study \\
H15149 & CBr.4 & cytb & 5'-CCTCARAAGGATATYTGTCCTCA-3' & This study \\
L15513c & CBf.2 & cytb & 5'-CTRGGAGACCCNGAAAACTT-3' & This study \\
L15923 & THRf.4 & tRNA ${ }^{\text {thr }}$ & 5'-AACACAAAGCATCGGTCTTGTAA-3' & This study \\
H15976 & PROr.2 & tRNA ${ }^{\text {Pro }}$ & 5'-TAGCTTTGGGAGTTAAGGGTGGG-3' & This study \\
L15995 & Prof.1 & tRNA ${ }^{\text {Pro }}$ & 5'-CTCYCACCCCTGACTCCCAAAG-3' & This study \\
\hline
\end{tabular}

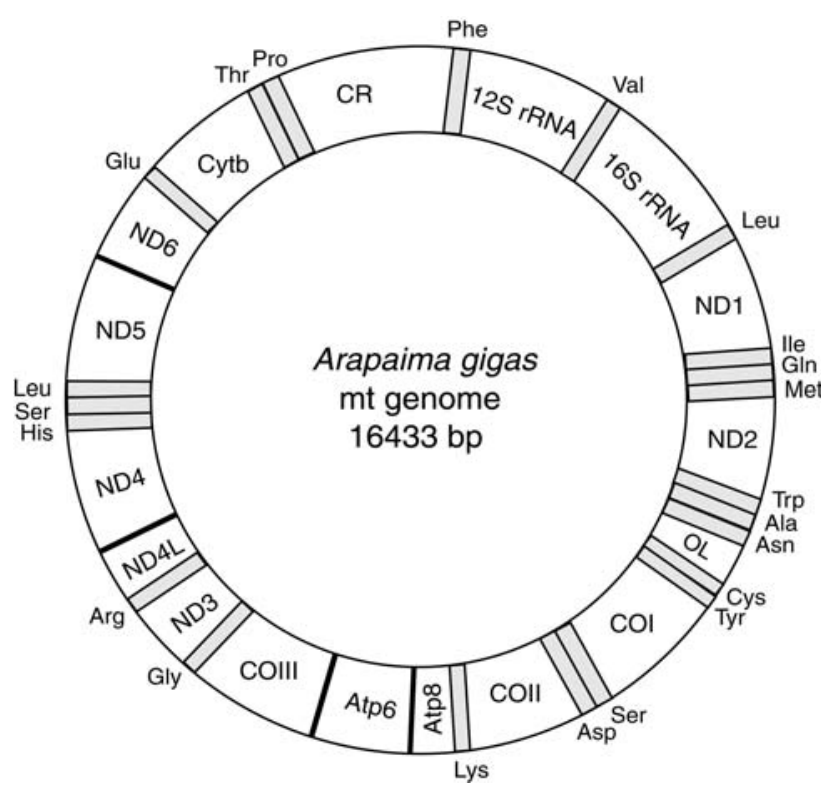

Figure 1 - Schematic map of the complete mitochondrial genome of Arapaima gigas.

subunit of the Cytochrome $b(\mathrm{cob})$ which forms part of the ubiquinol cytochrome $c$ oxidoreductase complex; three subunits of the Cytochrome oxidase (cox) which form part of the cytochrome c oxidase complex; seven subunits of the NADH dehydrogenase (nad) which form part of the nico- tinamide adenine dinucleotide ubiquinone oxidoreductase complex; and two subunits of ATP synthase (atp). It also contains the small $(r r n S)$ subunit and the large $(r r n L)$ subunit ribosomal RNA genes and 22 tRNA genes (trn). A noncoding control region located between $\operatorname{trn} P$ and $\operatorname{trn} F$ genes contains the origin of heavy strand replication $\left(\mathrm{O}_{\mathrm{H}}\right)$, and the light strand replication origin $\left(\mathrm{O}_{\mathrm{L}}\right)$ is found between the tRNAs genes $\operatorname{trn} N$ and $\operatorname{trn} C$.

The reference Arapaima gigas individual that we sequenced had a relatively short control region of $787 \mathrm{bp}$. A schematic representation is shown in Figure 2. Similar to typical vertebrate mitochondrion, this non-coding region contains the heavy-strand replication origin $\left(\mathrm{O}_{\mathrm{H}}\right)$ and can be divided into three different domains (Brown et al., 1986). Domain I is only 147 nucleotides long and contains a $23 \mathrm{bp}$ thermo-stable hairpin suggested to be involved in the regulation of replication of the mitochondrial genome (Buroker et al., 1990); however, it does not appear to contain the termination associated sequence (Doda et al., 1981). Domain II, the central conserved block, extended from nucleotide 148 to 386 . Domain III contained three conserved sequence blocks (CSB-1 at position 461-486; CSB-2 at position 577-593; and CSB-3 at position 620-637). Similar to the results reported by Broughton (2001), the CSB-1 was the least conserved, while CSB-3 was the most highly conserved of the three blocks. In do- 
Table 2 - Gene organization of the Arapaima gigas mitochondrial genome.

\begin{tabular}{|c|c|c|c|c|c|}
\hline Gene/element & Strand & Position & Size & Start & Stop \\
\hline $\operatorname{trn} F$ & $\mathrm{H}$ & $1 . .68$ & 69 & - & - \\
\hline$r r n S$ & $\mathrm{H}$ & $69 . .1022$ & 954 & - & - \\
\hline $\operatorname{trn} V$ & $\mathrm{H}$ & $1023 . .1093$ & 71 & - & - \\
\hline$r r n L$ & $\mathrm{H}$ & $1094 . .2779$ & 1686 & - & - \\
\hline $\operatorname{trn} L$ (TAA) & $\mathrm{H}$ & $2780 . .2853$ & 74 & - & - \\
\hline nadl & $\mathrm{H}$ & $2858 . .3829$ & 972 & ATG & TAA \\
\hline $\operatorname{trnI}$ & $\mathrm{H}$ & $3831 . .3902$ & 72 & - & - \\
\hline $\operatorname{trn} Q$ & $\mathrm{~L}$ & $3903 . .3972$ & 70 & - & - \\
\hline $\operatorname{trn} M$ & $\mathrm{H}$ & $3972 . .4040$ & 69 & - & - \\
\hline $\operatorname{nad} 2$ & $\mathrm{H}$ & $4041 . .5085$ & 1045 & ATG & $\mathrm{T}^{*}$ \\
\hline $\operatorname{trn} W$ & $\mathrm{H}$ & $5086 . .5154$ & 69 & - & - \\
\hline $\operatorname{trn} A$ & $\mathrm{~L}$ & $5156 . .5224$ & 69 & - & - \\
\hline $\operatorname{trn} N$ & $\mathrm{~L}$ & $5226 . .5298$ & 73 & - & - \\
\hline $\mathrm{O}_{\mathrm{L}}$ & $\mathrm{L}$ & $5299 . .5334$ & 36 & - & - \\
\hline $\operatorname{trn} C$ & $\mathrm{~L}$ & $5335 . .5401$ & 67 & - & - \\
\hline $\operatorname{trn} Y$ & $\mathrm{~L}$ & $5402 . .5472$ & 71 & - & - \\
\hline $\operatorname{cox} 1$ & $\mathrm{H}$ & $5474 . .7030$ & 1557 & GTG & AGA \\
\hline $\operatorname{trn} S$ (TGA) & $\mathrm{L}$ & 7026..7097 & 72 & - & - \\
\hline $\operatorname{trn} D$ & $\mathrm{H}$ & $7101 . .7172$ & 72 & - & - \\
\hline $\operatorname{cox} 2$ & $\mathrm{H}$ & $7177 . .7867$ & 691 & ATG & $\mathrm{T}^{*}$ \\
\hline $\operatorname{trn} K$ & $\mathrm{H}$ & $7868 . .7941$ & 74 & - & - \\
\hline atp 8 & $\mathrm{H}$ & $7943 . .8110$ & 168 & ATG & TAA \\
\hline atp6 & $\mathrm{H}$ & $8101 . .8784$ & 684 & ATG & TAA \\
\hline $\operatorname{cox} 3$ & $\mathrm{H}$ & $8784 . .9568$ & 785 & ATG & $\mathrm{T}^{*}$ \\
\hline $\operatorname{trn} G$ & $\mathrm{H}$ & $9569 . .9639$ & 71 & - & - \\
\hline $\operatorname{nad} 3$ & $\mathrm{H}$ & $9640 . .9988$ & 349 & ATG & $\mathrm{T}^{*}$ \\
\hline $\operatorname{trn} R$ & $\mathrm{H}$ & $9989 . .10058$ & 70 & - & - \\
\hline $\operatorname{nad} 4 \mathrm{~L}$ & $\mathrm{H}$ & $10059 . .10355$ & 297 & ATG & TAA \\
\hline $\operatorname{nad} 4$ & $\mathrm{H}$ & $10349 . .11738$ & 1390 & ATG & $\mathrm{T}^{*}$ \\
\hline $\operatorname{trn} H$ & $\mathrm{H}$ & $11739 . .11807$ & 69 & - & - \\
\hline $\operatorname{trn} S(\mathrm{GCT})$ & $\mathrm{H}$ & $11808 . .11875$ & 68 & - & - \\
\hline $\operatorname{trn} L(\mathrm{TAG})$ & $\mathrm{H}$ & $11876 . .11948$ & 73 & - & - \\
\hline nad5 & $\mathrm{H}$ & $11949 . .13790$ & 1842 & ATG & TAA \\
\hline nad6 & $\mathrm{L}$ & $13787 . .14317$ & 531 & ATG & TAA \\
\hline $\operatorname{trn} E$ & $\mathrm{~L}$ & $14318 . .14385$ & 68 & - & - \\
\hline$c o b$ & $\mathrm{H}$ & $14390 . .15530$ & 1141 & ATG & $\mathrm{T}^{*}$ \\
\hline $\operatorname{trn} T$ & $\mathrm{H}$ & $15531 . .15602$ & 72 & - & - \\
\hline $\operatorname{trn} P$ & $\mathrm{~L}$ & $15603 . .15666$ & 64 & - & - \\
\hline $\mathrm{O}_{\mathrm{H}}$ (control region) & $\mathrm{H}$ & $15667 . .16433$ & 767 & - & - \\
\hline
\end{tabular}

* = TAA stop codon is completed by the addition of 3' Adenine residues to the mRNA.

main III, a 14 unit AT repeat is present from position 678-705 and shortly thereafter it is followed by mono-nucleotide adenine and thiamine repeats. Repeat sequences are $5 \mathrm{~A}$ residue, $11 \mathrm{~T}$ residue, $6 \mathrm{~T}$ residue and $9 \mathrm{~A}$ residue mono-nucleotide repeats separated by short non-repeat sequence regions. As expected, the control re-

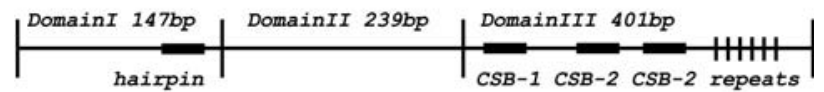

AGATTCTCAT TAAAACTATT CTCTGAAACT TAACAATAAC CCCACACCCA CATGCAAGTA TCCGCCAATT TATATATATG TATTATCGTG CATATTGTCT TTTACCCATT CACATGTACT agcacattac atgtTtCATC tTACATAtag tagtgagaAC haixpin

CCGCCAACTG ATGATTTCAC GAAATACTCT TAATGATAG' GCTAGACAAT AATTGCAAGT TTACACAACT GAATTATTAC AGGCATCTGA TTCCTTTTTC AGGAACAATA ATGAGAACAA TCCACAATAA TTTATTTCTA AAGTGCATTG ACTAATGCGC TCAACCTTAA GTTCGTTACC CACCAAGCCT AGCATTGAAT CCCCCCATAG GTTTTTATCT TTTTGGGGGG GAAATCACTT ACATTCCGGT TGTCCCTCCT ATGCAATATA AGGTAGGATA ATTATTGCAT GGGATTCCAA TATTAATTCA TGTTAGAAAG ACATAACTCA AGAATCGCAT AACTTGTATT AAGTGCATAG CSB-1

AGTTATTTAT ACCTGAAAAG TCTACGATCC TATTCCACCC CCCGCCACGC GCGCGTTAAA CCCCCCCTCC CCCATCATCC

$$
\text { CSB-2 }
$$

TACAAGTCCT ATGTAATTCC GTTAAACCCC TAAACCGGAA CSB-3

AAGACCAAGA ATGTGGTCCA CTACGCCCCT TCACATCATA TATATATATA TATAtatata TATATAGTTA AAAATTTTTT repeats

TTTTTAATAT ACATAGAATT TTTTATAAAA AAAAACATAA ACATAGAAGA ATAGAAAAGT AAGCGAG

Figure 2 - Schematic map characterizing of the control region of Arapaima gigas. Indicated are the three domains, a potentially regulatory hairpin in domain 1 , the three conserved sequence blocks in domain 3 , and a series of repeats in domain 3 .

gion is heavily biased against guanine with a composition of $0.342(\mathrm{~A}), 0.217(\mathrm{C}), 0.132(\mathrm{G})$, and $0.309(\mathrm{~T})$. The control region for $\mathrm{O}_{\mathrm{L}}$ contains a highly conserved hairpin loop with a perfectly complementary bases-pairing stem (CCTCCGCCT/AGGCGGGAGG). The secondary structure of the $\mathrm{O}_{\mathrm{L}}$ has been suggested to regulate light-strand replication (Wong and Clayton, 1985).

With the exception of cox 1 which starts with GTG, all protein-coding genes begin with the ATG start codon; stop codons include 12 TAA, six of which are incomplete, and one AGA (Table 2). Incomplete stop codons are common in mitochondrial genes, and TAA stop codons are created via posttranscriptional polyadenylation of the 3 ' end of the mRNA (Ojala et al., 1981). Reading frames of three pairs of genes, atp8-atp6, nad4L - nad4 and nad5-nad6 overlap by several nucleotides, a pattern which is also common in other vertebrate mitochondrial genomes. Some genes are separated by up to five nucleotide non-coding spacers (Table 2).

Codon usage in the 13 coding genes consisted of $28.4 \% \mathrm{~A}, 26.1 \% \mathrm{C}, 13.8 \% \mathrm{G}$ and $30.7 \% \mathrm{~T}$ bases. These values were similar to those observed in other osteoglossiform fishes and show a strong anti-G bias. The anti-G bias was especially pronounced in the third position of the 12 heavy-strand encoded genes which consisted of $41.7 \% \mathrm{~A}$, $28.1 \% \mathrm{C}, 3.8 \% \mathrm{G}$ and $26.4 \% \mathrm{~T}$ bases (Figure 3; Table 3). The rank order of nucleotide usage frequency at the third codon position is the same as in Osteoglossum bicirrhosus and Pantodon buch holzi; however, in Scleropage formosus the rank order of $\mathrm{A}$ and $\mathrm{C}$ is reversed. The most frequently 

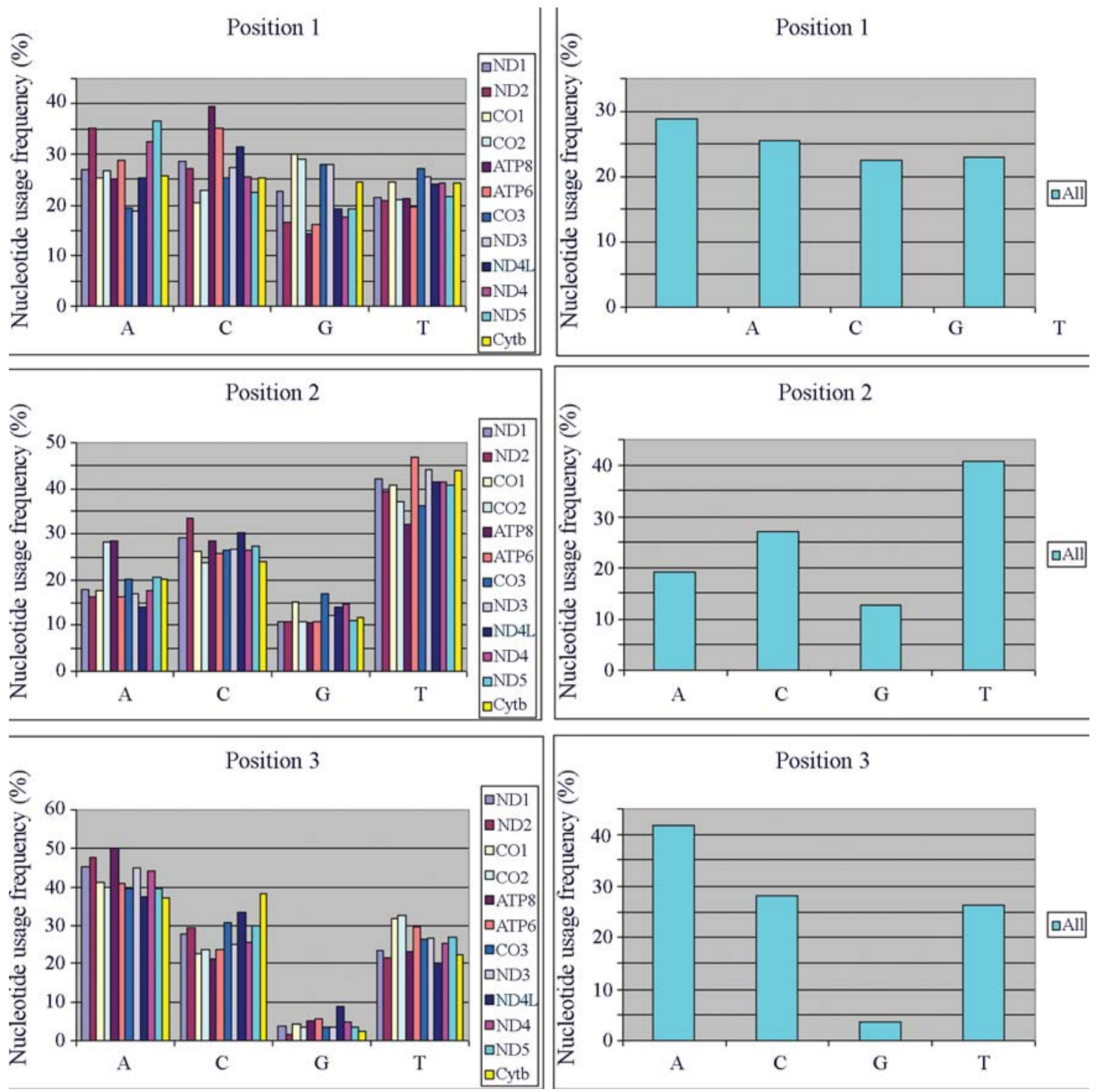

Figure 3 - Nucleotide composition of the 12 mitochondrial genes coded on the heavy strand. Nucleotide composition at first, second and third positions for individual genes is presented on the left side. On the right side, averages across all genes are presented.

encoded amino acids were leucine (16.65\%), followed by threonine $(8.25 \%)$, isoleucine $(8.17 \%)$ and alanine $(7.72 \%)$. The least common amino acid was cystein $(0.79 \%)$ - see Table 4.

All 22 Arapaima mitochondrial tRNA genes possess anticodons that match the vertebrate mitochondrial genetic code (Kumazawa and Nishida, 1993). Each tRNA sequence may be folded into a cloverleaf structure with $7 \mathrm{bp}$ in the

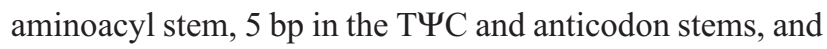
$4 \mathrm{bp}$ in the DHU stem. tRNA stem regions include some non-complementary base pairings, a pattern also commonly observed in other vertebrates (e.g., Kumazawa and Nishida, 1993). The 3' CCA nucleotide tail of mature tRNAs is most likely added post-transcriptionally (Roe et al., 1985).
When the $r r n S$ and $r r n L$ genes are transcribed into putative rRNAs, both rRNA sequences may also be folded into secondary structures. Stem regions appear to be conserved, whereas loop regions are somewhat more variable relative to other vertebrate sequences. The functional requirement for specific base pairing appears to constrain the evolution of stems relative to some portions of loops (e.g., Sullivan et al., 1995; Ortí et al., 1996; Wang and Lee, 2002).

\section{Discussion}

One of the motivations of our study was to sequence the mitochondrial control region, and determine the factors which impeded its efficient use in phylogeographic and population genetic analyses (Hrbek et al., 2005). In spite of designing specific, highly stringent primers, Hrbek et al. 
Table 3 - Codon usage of the Arapaima gigas mtDNA.

\begin{tabular}{|c|c|c|c|c|c|c|c|}
\hline \multirow{2}{*}{$\begin{array}{l}\text { Amino acid } \\
\text { (anticodon) }\end{array}$} & \multirow{2}{*}{$\begin{array}{l}\text { Codon } \\
\text { group }\end{array}$} & \multicolumn{4}{|c|}{ Usage of codon ending in } & \multirow[t]{2}{*}{ Total } & \multirow[t]{2}{*}{$\%$} \\
\hline & & $\mathrm{A}$ & $\mathrm{C}$ & $\mathrm{G}$ & $\mathrm{T}$ & & \\
\hline Ala (UGC) & GCN & 94 & 108 & 4 & 88 & 294 & 7.53 \\
\hline Cys (GCA) & TGY & 0 & 19 & 0 & 11 & 30 & 0.77 \\
\hline Asp (GUC) & GAY & 0 & 37 & 0 & 39 & 76 & 1.95 \\
\hline Glu (UUC) & GAR & 90 & 0 & 6 & 0 & 96 & 2.46 \\
\hline Phe (GAA) & TTY & 0 & 120 & 0 & 127 & 247 & 6.33 \\
\hline Gly (UCC) & GGN & 92 & 63 & 35 & 46 & 236 & 6.05 \\
\hline His (GUG) & CAY & 0 & 66 & 0 & 45 & 111 & 2.84 \\
\hline Ile (GAU) & ATY & 0 & 110 & 0 & 201 & 311 & 7.97 \\
\hline Lys (UUU) & AAR & 82 & 0 & 5 & 0 & 87 & 2.23 \\
\hline Leu (UAG) & $\mathrm{CTN}+\mathrm{TTR}$ & 367 & 116 & 44 & 107 & 634 & 16.24 \\
\hline Met (CAU) & ATR & 146 & 0 & 40 & 0 & 186 & 4.77 \\
\hline Asn (GUU) & AAY & 0 & 70 & 0 & 64 & 134 & 3.43 \\
\hline Pro (UGG) & $\mathrm{CCN}$ & 122 & 36 & 7 & 43 & 208 & 5.33 \\
\hline Gln (UUG) & CAR & 94 & 0 & 94 & 0 & 188 & 4.82 \\
\hline $\operatorname{Arg}(\mathrm{UCG})$ & CGN & 44 & 12 & 4 & 12 & 72 & 1.84 \\
\hline Ser (UGA) & $\mathrm{TCN}+\mathrm{AGY}$ & 89 & 99 & 4 & 60 & 252 & 6.46 \\
\hline Thr (UGU) & $\mathrm{ACN}$ & 139 & 86 & 8 & 81 & 314 & 8.05 \\
\hline Val (UAC) & GTN & 86 & 35 & 12 & 54 & 187 & 4.79 \\
\hline Trp (UCA) & TGR & 111 & 0 & 9 & 0 & 120 & 3.07 \\
\hline Tyr (GUA) & TAY & 0 & 49 & 0 & 64 & 113 & 2.90 \\
\hline Stop (UUA) & TAR & 5 & 0 & 1 & 0 & 6 & 0.15 \\
\hline Stop (UCA) & TGR & 1 & 0 & 0 & 0 & 1 & 0.03 \\
\hline Total & & 1562 & 1026 & 273 & 1042 & 3903 & 100.00 \\
\hline
\end{tabular}

(2005) were unable to obtain amplification results in the majority of the individuals used in their conservation genetic study. Not all individuals amplified, and those that did, often produced only a weak product often with large size differences among PCR products. PCR amplification of a number of individuals also produced multiple bands suggesting possible mtDNA heteroplasmy. Inoue et al. (2001) encountered similar difficulties (pers. com.), and for these reasons did not characterize the control regions of the two osteoglossiform species Osteoglossum bicirrhosum (GenBank\# AB043025) and Pantodon buchholzi (GenBank\# AB043068). A recent study of Yue et al. (2006) characterized the complete mitochondrial genome of the Asian arowana Scleropages formosus and reported tandem repeats in the 5' and 3' ends of the control region, as well as mitochondrial heteroplasmy. These observations suggest that the control region anomalies observed in Arapaima may be a general property of the control regions of the fishes of the order Osteoglossiformes.

The control region of the reference specimen of Arapaima gigas is relatively short at $787 \mathrm{bp}$. It contains three domains (Brown et al., 1986). Domain I appears to lack the termination associated sequence (Doda et al., 1981), but it does contain a 23 bp thermo-stable hairpin (Figure 2). The hairpin contains the ATGTA/TACAT motif which Yue et al. (2006) also observed in other osteoglossiform fishes and in fishes of the genus Anguilla. Previously this motif was observed only in mammals (Saccone et al., 1991) and the lungfish (Zardoya and Meyer, 1996). Although not pointed out by Yue et al. (2006), the hairpin is actually inverted (TACAT/ATGTA) in the phylogenetically closely related Asian (Scleropages formosus) and the silver (Osteoglossum bicirrhosus) arowanas, but not in other osteoglossiform species. The inverted repeat appears to be a molecular synapomorphy for the Scleropages + Osteoglossum clade. Same as in Scleropages formosus, domain III of Arapaima gigas contains microsatellite repeats; specifically domain III of the reference individuals contains a 14 unit AT repeat followed by mono-nucleotide repeat sequences of A (5x), T (11x), T (6x) and A (9x). Repeats in both the 5' end (domain I) and the 3' end (domain III) of the control region are rare and currently have only been reported in Scleropages formosus (GenBank\# DQ023143, Yue et al., 2006).

Although only preliminarily characterized, a similar pattern of repeats is observed in the 5' and 3' ends of the control region of Heterotis niloticus, the African sister taxon of Arapaima gigas. The control regions of Osteoglossum bicirrhosum (GenBank\# AB043025) and the African Pantodon buchholzi (GenBank\# AB043068) also 
Table 4 - Amino acid usage (\%) in the 13 protein coding genes of the Arapaima gigas mtDNA.

\begin{tabular}{|c|c|c|c|c|c|c|c|c|c|c|c|c|c|c|}
\hline & ND1 & ND2 & $\mathrm{CO} 1$ & $\mathrm{CO} 2$ & ATP8 & ATP6 & $\mathrm{CO} 3$ & ND3 & ND4L & ND4 & ND5 & ND6 & Cytb & Avg \\
\hline Ala & 9.91 & 8.91 & 8.30 & 5.22 & 1.82 & 7.05 & 8.43 & 8.62 & 9.18 & 5.83 & 7.50 & 9.66 & 7.37 & 7.72 \\
\hline Cys & 0.00 & 0.29 & 0.19 & 0.87 & 0.00 & 0.44 & 1.15 & 0.86 & 3.06 & 1.08 & 1.14 & 1.70 & 0.79 & 0.79 \\
\hline Asp & 0.93 & 0.00 & 2.70 & 5.65 & 1.82 & 0.44 & 1.92 & 4.31 & 1.02 & 1.30 & 2.12 & 1.70 & 2.89 & 2.00 \\
\hline Glu & 3.41 & 1.72 & 2.12 & 5.22 & 1.82 & 1.32 & 3.83 & 5.17 & 2.04 & 2.38 & 1.79 & 3.41 & 1.58 & 2.52 \\
\hline Phe & 6.19 & 4.31 & 9.07 & 3.91 & 5.45 & 5.73 & 8.81 & 7.76 & 7.14 & 3.67 & 7.18 & 5.68 & 7.89 & 6.49 \\
\hline Gly & 5.26 & 4.60 & 9.27 & 3.48 & 1.82 & 4.41 & 8.05 & 5.17 & 5.10 & 5.18 & 5.06 & 14.20 & 6.32 & 6.20 \\
\hline His & 1.24 & 2.01 & 3.47 & 4.78 & 10.91 & 3.08 & 5.75 & 0.86 & 5.10 & 2.16 & 2.61 & 0.00 & 2.89 & 2.91 \\
\hline Ile & 9.60 & 8.91 & 7.53 & 8.26 & 3.64 & 10.13 & 4.98 & 6.90 & 4.08 & 9.94 & 9.14 & 3.41 & 8.68 & 8.17 \\
\hline Lys & 2.48 & 2.87 & 1.74 & 2.61 & 3.64 & 0.44 & 1.15 & 0.86 & 0.00 & 3.24 & 3.43 & 0.57 & 2.63 & 2.28 \\
\hline Leu & 19.50 & 19.83 & 11.39 & 10.00 & 10.91 & 25.11 & 13.03 & 20.69 & 23.47 & 19.44 & 15.17 & 17.61 & 16.32 & 16.65 \\
\hline Met & 3.41 & 4.89 & 5.21 & 5.22 & 5.45 & 3.08 & 3.45 & 3.45 & 5.10 & 5.62 & 6.53 & 5.11 & 4.21 & 4.88 \\
\hline Asn & 4.33 & 4.02 & 2.70 & 2.17 & 3.64 & 3.52 & 0.38 & 1.72 & 2.04 & 2.81 & 6.20 & 1.70 & 4.74 & 3.52 \\
\hline Pro & 7.12 & 5.75 & 5.79 & 6.52 & 14.55 & 5.73 & 4.98 & 6.90 & 3.06 & 5.62 & 3.75 & 2.84 & 5.53 & 5.46 \\
\hline Gln & 2.17 & 3.74 & 1.74 & 3.48 & 5.45 & 4.85 & 2.68 & 2.59 & 3.06 & 2.38 & 3.10 & 0.00 & 1.58 & 2.63 \\
\hline Arg & 2.48 & 1.15 & 1.54 & 2.61 & 0.00 & 2.64 & 2.3 & 1.72 & 2.04 & 2.38 & 1.31 & 2.27 & 1.84 & 1.89 \\
\hline Ser & 6.50 & 7.47 & 5.79 & 6.96 & 3.64 & 4.85 & 5.75 & 5.17 & 10.20 & 7.34 & 7.99 & 5.68 & 5.79 & 6.62 \\
\hline Thr & 6.50 & 12.93 & 7.14 & 6.96 & 9.09 & 10.13 & 8.43 & 6.03 & 11.22 & 9.29 & 9.79 & 1.70 & 5.53 & 8.25 \\
\hline Val & 3.41 & 1.44 & 7.53 & 9.57 & 7.27 & 3.08 & 6.13 & 5.17 & 2.04 & 2.81 & 2.77 & 11.36 & 6.58 & 4.91 \\
\hline Trp & 2.48 & 3.16 & 3.47 & 2.17 & 9.09 & 1.76 & 4.60 & 4.31 & 1.02 & 4.32 & 2.12 & 3.98 & 2.89 & 3.15 \\
\hline Tyr & 3.10 & 2.01 & 3.28 & 4.35 & 0.00 & 2.20 & 4.21 & 1.72 & 0.00 & 3.24 & 1.31 & 7.39 & 3.95 & 2.97 \\
\hline Total & 323 & 348 & 518 & 230 & 55 & 227 & 261 & 116 & 98 & 463 & 613 & 176 & 380 & 292.9 \\
\hline
\end{tabular}

contain a large and complex tandem repeats in the 5' end of the control region which corresponds to the domain I hairpin (Yue et al., 2006). However, confirmation of the exact pattern and structure of the control regions of these species is not possible since the central and 3' end portions of the control regions are not available. The control region of the mormyriid Gnathonemus petersii lacks large blocks of repeats, and appears to contain all three CSBs. The mormyriids together with hiodontids and notopterids are sister clade to the clade containing the genera Arapaima, Heterotis, Sclerophages, Osteoglossum and Pantodon (Nelson, 1994; Sullivan et al., 2000), which suggests that the observed control region peculiarities are phylogenetically restricted.

The mitochondrial control region regulates replication of the heavy strand and transcription (see review in Shadel and Clayton, 1997). Together with the conserved sequence blocks whose role is involved in positioning RNA polymerase for transcription and for priming replication (Clayton, 1991; Shadel and Clayton, 1997), an important regulatory element is the termination associated sequence (TAS) normally observed in domain I. TAS appears to act as a signal for termination of D-loop strand synthesis, however, it could not be identified in our reference individual. We speculate that the $23 \mathrm{bp}$ thermo-stable hairpin found in domain I (Figure 2) may take on the role of a signal for termination of D-loop strand synthesis in the absence of TAS. This conclusion is contrary to that of Yue et al. (2006) who suggest that the domain I hairpin may be a binding site for proteins involved in replication. Elucidating the role of the domain I hairpin and understanding the consequence of the apparent lack of TAS for mitochondrial replication and for the transcription of mitochondrial genes, if any, will require biochemical and cell molecular studies, however. The second major regulatory region, the light strand replication origin, is found between the genes $\operatorname{trnN}$ and $\operatorname{trn} C$. It is represented by a 35-bp non-coding sequence which may be folded into secondary structure consisting of a perfect 9-bp stem and a 13-bp loop. Secondary structures at the light strand replication origin may act as initiation signals for light strand replication (Wong and Clayton, 1985) and appear to be fully functional.

Protein coding genes are characterized by an anti-G bias which is particularly strong at the third codon position where $\mathrm{G}$ is present at only $3.8 \%$ frequency (Figure 3; Table 3 ). The anti-G bias may be due in part to selection against less stable $\mathrm{G}$ nucleotides on the light strand, which is exposed as a single strand for a considerable length of time during the asymmetrical replication of mtDNA (Clayton, 1982). A further implication of the model of Clayton (1982) has been pointed out by Reyes et al. (1998). The deamination of cytosine into uracil and adenine into hypoxanthine on the heavy strand would lead to a decrease in $G$ content in the light strand, and an increase in $\mathrm{G}$ on the heavy strand. The low $\mathrm{G}$ content observed in mitochondrial genes may, thus, also be a result of the asymmetrical replication 
of the mitochondrial genome. Still further contribution to the anti-G bias may result from the preference for adenine during mRNA transcription, as ATP is generally the most common ribonucleotide available in the mitochondria and, thus, is most efficiently transcribed (Xia, 1996). In contrast to $\mathrm{G}$, the most commonly used nucleotide is A which is also the most commonly used nucleotide in Osteoglossum bicirrhosum and Pantodon buchholzi, but not in Scleropages formosus. Amino acid usage is also similar to that observed in other osteoglossiform fishes, and is heavily biased towards the use of leucine.

It is clear that the control region patterns, or their variations, observed in Arapaima gigas are also observed in other osteoglossiform fishes. What is unclear is if these control region characteristics are due to phylogenetic conservatism, or due to homoplasy. No matter what the mechanism, the control region is unlikely to be a suitable phylogenetic marker for phylogeographic and population-level studies due to large stretches of repeats and secondary structures which make amplification and sequencing difficult. Further complications arise due to mitochondrial heteroplasmy potentially caused by slip-strand replication (Macey et al., 1997c) of the domain I hairpin and or of the domain III microsatellite region.

The availability of the complete genome of Arapaima gigas will facilitate molecular population studies of both the pirarucu and other osteoglossiform fishes, such as the two species of arowana Osteoglossum bicirrhosum and Osteoglossum ferreirai, and the aquiculturally important African species Heterotis niloticus. The mitochondrial genome is composed of a mosaic of highly conserved and highly variable sections among the evolutionarily divergent Arapaima gigas and Osteoglossum bicirrhosum. This characteristic greatly facilitates choosing appropriately informative genomic regions for particular questions, as well as primer design for other osteoglossiform species.

\section{Acknowledgments}

This research was supported by a research grant from the Fundação de Amparo a Pesquisa do Estado do Amazonas (FAPEAM) to IPF. Permission to conduct fieldwork and to collect tissue samples was granted by IBAMA (License n. 48/2000), and to conduct genetic assessment by CGEN/IBAMA (Deliberation n. 75). We thank Marcelo Crossa for helping us obtain tissue samples, and two anonymous reviewers for suggestions. TH acknowledges FAPEAM and the J. William Fulbright Foundation for financial support.

\section{References}

Anderson SA, Bankier T, Barrell BG, de Bruijn MHL, Coulson AR, Drouin J, Eperon IC, Nierlich DP, Roe BA, Sanger F, et al. (1981) Sequence and organization of the human mitochondrial genome. Nature 290:457-465.
Avise JC (2004) Molecular Markers, Natural History and Evolution. 2nd ed. Sinauer Associates, Sunderland, 541 pp.

Boore JL (1999) Animal mitochondrial genomes. Nucleic Acids Res 27:1767-1780.

Boore JL and Brown WM (1998) Big trees from little genomes: Mitochondrial gene order as a phylogenetic tool. Curr Op Gen Dev 8:668-674.

Boore JL, Lavrov D and Brown WM (1997) Mitochondrial gene rearrangements trace metazoan phylogeny. Am Zool 37:70A.

Brinkmann H, Denk A, Zitzler J, Joss JJ and Meyer A (2004) Complete mitochondrial genome sequences of the South American and the Australian lungfish: Testing of the phylogenetic performance of mitochondrial data sets for phylogenetic problems in tetrapod relationships. J Mol Evol 59:834-848.

Broughton RE, Milam JE and Roe BA (2001) The complete sequence of the Zebrafish (Danio rerio) mitochondrial genome and evolutionary patterns in vertebrate mitochondrial DNA. Genome Res 11:1958-1967.

Brown GG, Gadaleta G, Pepe G, Saccone C and Sbis E (1986) Structural conservation and variation in the D-loopcontaining region of vertebrate mitochondrial DNA. J Mol Biol 192:503-511.

Brown WM (1985) The mitochondrial genome of animals. In: MacIntyre RJ (ed) Molecular Evolutionary Genetics. Plenum Press, New York, pp 95-130.

Buroker NE, Brown JR, Gilbert TA, O'Hara PA, Beckenback AT, Thomas WK and Smith MJ (1990) Length heteroplasmy of sturgeon mitochondrial DNA: An illegitimate elongation model. Genetics 124:157-163.

Clayton DA (1982) Replication of animal mitochondrial DNA. Cell 28:693-705.

Clayton DA (1991) Nuclear gadgets in mitochondrial DNA replication and transcription. Trends Biotech 16:107-111.

Curole JP and Kocher TD (1999) Mitogenomics: Digging deeper with complete mitochondrial genomes. Trends Ecol Evol 14:394-398.

Doda JN, Wright CT and Clayton DA (1981) Elongation of displacement-loop strands in human and mouse mitochondrial DNA is arrested near specific template sequences. Proc Natl Acad Sci USA 78:6116-6120.

Hall T (1999) BioEdit: A user-friendly biological sequence alignment editor and analysis program for Windows 95/98/NT. Nucleic Acids Symp Ser 41:95-98.

Haring E, Kruckenhauser L, Gamauf A, Riesing MJ and Pinsker W (2001) The complete sequence of the mitochondrial genome of Buteo buteo (Aves, Accipitridae) indicates an early split in the phylogeny of raptors. Mol Biol Evol 18:18921904.

Hrbek T and Larson A (1999) The evolution of diapause in the killifish family Rivulidae (Atherinomorpha, Cyprinodontiformes): A molecular phylogenetic and biogeographic perspective. Evolution 53:1200-1216.

Hrbek T, Farias IP, Crossa M, Sampaio I, Porto JIR and Meyer A (2005) Population genetic analysis of Arapaima gigas, one of the largest freshwater fishes of the Amazon basin: Implications for its conservation. Anim Conserv 8:297-308.

Inoue JG, Miya M, Tsukamoto K and Nishida M (2001) A mitogenomic prespective on the basal teleostean phylogeny: Re- 
solving higher-level relationships with longer DNA sequences. Mol Phylogenet Evol 20:275-285.

Inoue JG, Miya M, Tsukamoto K and Nishida M (2003a) Basal actinopterygian relationships: A mitogenomic perspective on the phylogeny of the "ancient fish". Mol Phylogenet Evol 26:110-120.

Inoue JG, Miya M, Tsukamoto K and Nishida M (2003b) Evolution of the deep-sea Gulper eel mitochondrial genomes: Large-scale gene rearrangements originated within the eels. Mol Biol Evol 20:1917-1924.

Kumar S, Tamura K and Nei M (2004) MEGA3: Integrated software for molecular evolutionary genetics analysis and sequence alignment. Briefings Bioinfor 5:150-163.

Kumazawa Y and Nishida M (1993) Sequence evolution of mitochondrial tRNA genes and deep-branch animal phylogenetics. J Mol Evol 37:380-398.

Macey JR, Larson A, Ananjeva NB, Fang Z and Papenfuss TJ (1997a) Two novel gene orders and the role of light-strand replication in the rearrangement of the vertebrate mitochondrial genome. Mol Biol Evol 14:91-104.

Macey JR, Larson A, Ananjeva NB and Papenfuss TJ (1997b) Evolutionary shifts in three major structural features of the mitochondrial genome among iguanian lizards. J Mol Evol 44:660-674.

Macey JR, Larson A, Ananjeva NB and Papenfuss TJ (1997c) Replication slippage may cause parallel evolution in the secondary structures of mitochondrial transfer RNAs. Mol Biol Evol 14:31-39.

Mindell DP, Sorenson MD and Dimcheff DE (1998) Multiple independent origins of mitochondrial gene order in birds. Proc Natl Acad Sci USA 95:10693-10697.

Miya M, Kawaguchi A and Nishida M (2001) Mitogenomic exploration of higher teleostean phylogenies: A case study for moderate-scale evolutionary genomics with 38 newly determined complete mitochondrial DNA sequences. Mol Biol Evol 18:1993-2009.

Miya M and Nishida M (1999) Organization of the mitochondrial genome of a deep-sea fish, Gonostoma gracile (Teleostei, Stomiiformes): First example of transfer RNA gene rearrangements in bony fishes. Mar Biotech 1:416-426.

Miya M, Takeshima H, Endo H, Ishiguro NB, Inoue JG, Mukai T, Satoh TP, Yamaguchi M, Kawaguchi A and Mabuchi K (2003) Major patterns of higher teleostean phylogenies: A new perspective based on 100 complete mitochondrial DNA sequences. Mol Phylogenet Evol 26:121-138.

Morrison CL, Harvey AW, Lavery S, Tieu K, Huang Y and Cunningham CW (2002) Mitochondrial gene rearrangements confirm the parallel evolution of the crab-like form. Proc R Soc London B 269:345-350.

Naylor GJP and Brown WM (1998) Amphioxus mitochondrial DNA, chordate phylogeny, and the limits of inference based on comparisons of sequences. Syst Biol 47:61-76.

Nelson JS (1994) Fishes of the World. 3rd ed. John Wiley and Sons, Inc., New York, 624 pp.

Ojala D, Montoya J and Attardi G (1981) tRNA punctuation model of RNA processing in human mitochondria. Nature 290:470-474.
Ortí G, Petry P, Porto JIR, Jégu M and Meyer A (1996) Patterns of nucleotide changes in mitochondrial ribosomal RNA genes and the phylogeny of piranhas. J Mol Evol 42:169-182.

Pääbo S, Thomas WK, Whitfield KM, Kumazawa Y and Wilson AC (1991) Rearrangements of mitochondrial transfer RNA genes in marsupials. J Mol Evol 33:426-430.

Pereira SL (2000) Mitochondrial genome organization and vertebrate phylogenetics. Genet Mol Biol 23:745-752.

Reyes A, Gissi C, Pesole G and Saccone C (1998) Asymmetrical directional mutation pressure in the mitochondrial genome of mammals. Mol Biol Evol 15:957-966.

Roe BA, Ma D-P, Wilson RK and Wong JF-H (1985) The complete nucleotide sequence of the Xenopus laevis mitochondrial genome. J Biol Chem 260:9759-9774.

Saccone C, Pesole G and Sbisá E (1991) The main regulatory region of mammalian mitochondrial DNA: Structure-function model and evolutionary pattern. J Mol Evol 33:83-91.

Shadel GS and Clayton DA (1997) Mitochondrial DNA maintenance in vertebrates. Annu Rev Biochem 66:409-435.

Sullivan JP, Holsinger KE and Simon C (1995) Among-site rate variation and phylogenetic analysis of $12 \mathrm{~S}$ rRNA in sigmodontine rodents. Mol Biol Evol 12:988-1001.

Sullivan JP, Lavoué S and Hopkins CD (2000) Molecular systematics of the African electric fishes (Mormyroidea, Teleostei) and a model for the evolution of their electric organs. J Exp Biol 203:665-683.

Thompson JD, Higgins DG and Gibson TJ (1996) CLUSTAL W: Improving the sensitivity of progressive multiple sequence alignment through sequence weighting, position specific gap penalties and weight matrix choice. Nucleic Acids Res 22:4673-4680.

Wang H-Y and Lee S-C (2002) Secondary structure of mitochondrial 12S rRNA among fish and its phylogenetic applications. Mol Biol Evol 19:138-148.

Waters JM, Saruwatari T, Kobayashi T, Oohara I, McDowall RM and Wallis GP (2002) Phylogenetic placement of retropinnid fishes: Data set incongruence can be reduced by using asymmetric character state transformation costs. Syst Biol 51:432-449.

Wong TW and Clayton DA (1985) In vitro replication of human mitochondrial DNA: Accurate initiation at the origin of light-strand synthesis. Cell 42:951-958.

Xia X (1996) Maximizing transcription efficiency causes codon usage bias. Genetics 144:1309-1320.

Yue GH, Liew WC and Orban L (2006) The complete mitochondrial genome of a basal teleost, the Asian arowana (Scleropages formosus, Osteoglossidae). BMC Genomics 7:1-13.

Zardoya R and Meyer A (1996) The complete nucleotide sequence of the mitochondrial genome of the lungfish (Protopterus dolloi) supports its phylogenetic position as a close relative of land vertebrates. Genetics 142:1249-1263.

Zhang D-X and Hewitt GM (1996) Nuclear integrations: Challenges for mitochondrial DNA markers. Trends Ecol Evol $11: 247-251$

Zuker M (2003) Mfold web server for nucleic acid folding and hybridization prediction. Nucleic Acids Res 31:3406-3415.

Associate Editor: Antonio Solé-Cava

License information: This is an open-access article distributed under the terms of the Creative Commons Attribution License, which permits unrestricted use, distribution, and reproduction in any medium, provided the original work is properly cited. 